\title{
Interacting effects of vegetation components and water level on methane dynamics in a boreal fen
}

\author{
Terhi Riutta $^{1,2, a}$, Aino Korrensalo ${ }^{3}$, Anna M. Laine ${ }^{3}$, Jukka Laine ${ }^{1}$, and Eeva-Stiina Tuittila ${ }^{1,3}$ \\ ${ }^{1}$ Department of Forest Ecology, University of Helsinki, Helsinki, Finland \\ ${ }^{2}$ Department of Life Sciences, Imperial College London, Ascot, UK \\ ${ }^{3}$ School of Forest Sciences, University of Eastern Finland, Joensuu, Finland \\ ${ }^{a}$ current address: School of Geography and the Environment, University of Oxford, Oxford, UK
}

Correspondence: Eeva-Stiina Tuittila (eeva-stiina.tuittila@uef.fi)

Received: 1 September 2019 - Discussion started: 1 October 2019

Revised: 1 December 2019 - Accepted: 25 December 2019 - Published: 12 February 2020

\begin{abstract}
Vegetation and hydrology are important controlling factors in peatland methane dynamics. This study aimed at investigating the role of vegetation components, sedges, dwarf shrubs, and Sphagnum mosses, in methane fluxes of a boreal fen under natural and experimental water level drawdown conditions. We measured the fluxes during growing seasons 2001-2004 using the static chamber technique in a field experiment where the role of the ecosystem components was assessed via plant removal treatments. The first year was a calibration year after which the water level drawdown and vegetation removal treatments were applied. Under natural water level conditions, plant-mediated fluxes comprised $68 \%-78 \%$ of the mean growing season flux (1.73 \pm $0.17 \mathrm{~g} \mathrm{CH}_{4} \mathrm{~m}^{-2}$ month $^{-1}$ from June to September), of which Sphagnum mosses and sedges accounted for one-fourth and three-fourths, respectively. The presence of dwarf shrubs, on the other hand, had a slightly attenuating effect on the fluxes. In water level drawdown conditions, the mean flux was close to zero $\left(0.03 \pm 0.03 \mathrm{~g} \mathrm{CH}_{4} \mathrm{~m}^{-2}\right.$ month $\left.^{-1}\right)$ and the presence and absence of the plant groups had a negligible effect. In conclusion, water level acted as a switch; only in natural water level conditions did vegetation regulate the net fluxes. The results are relevant for assessing the response of fen peatland fluxes to changing climatic conditions, as water level drawdown and the consequent vegetation succession are the major projected impacts of climate change on northern peatlands.
\end{abstract}

\section{Introduction}

Approximately one-third of all terrestrial carbon is stored in boreal and subarctic peatlands (e.g., Yu, 2012) that generally act as $\mathrm{CO}_{2}$ sinks in current climatic conditions. However, pristine wetlands, including peatlands, marshes, and floodplains, are also the largest natural source of methane $\left(\mathrm{CH}_{4}\right)$ in the atmosphere (Ciais et al., 2014; Kirschke et al., 2013; Saunois et al., 2016). The carbon sink function of peatlands is mostly due to the slow decomposition rate resulting from waterlogged, anaerobic conditions sustained by a high water level, which simultaneously favor $\mathrm{CH}_{4}$ production. $\mathrm{CH}_{4}$ is the end product of anaerobic decomposition by strictly anaerobic methanogenic archaea. It is released from the peat into the atmosphere via diffusion through the peat column, ebullition or plant-mediated transport (Lai, 2009). A considerable part, from $20 \%$ to up to $90 \%$ (Le Mer and Roger, 2001; Pearce and Clymo, 2001; Whalen, 2005) of the $\mathrm{CH}_{4}$ diffusing through the upper, aerobic part of the peat layer is oxidized to $\mathrm{CO}_{2}$ by methanotrophic bacteria (MOB) before reaching the atmosphere.

Vegetation is a major factor controlling peatland $\mathrm{CH}_{4}$ fluxes (Koelbener et al., 2010; Ström et al., 2005, 2012). Fresh root litter and exudates are important substrates for the methanogenic microbes, and a significant proportion of the $\mathrm{CH}_{4}$ is formed from this easily available organic matter instead of from old, recalcitrant peat (Koelbener et al., 2010; Ström et al., 2012). Therefore, $\mathrm{CH}_{4}$ fluxes have a strong, positive correlation with the $\mathrm{CO}_{2}$ uptake (Bellisario et al., 1999; Christensen et al., 2000; Rinne et al., 2018), since 
higher primary productivity leads to a higher input of substrate. Of the vegetation components, deep-rooting aerenchymatous species such as sedges (Cyperaceae) and aerenchymatous herbs are especially important (Leppälä et al., 2011; Ward et al., 2013). In sedge-dominated wetlands, most of the $\mathrm{CH}_{4}$ is released through vascular plants (Kelker and Chanton, 1997; Ding et al., 2004; Ström et al., 2005), thus bypassing the aerobic peat layer where $\mathrm{CH}_{4}$ oxidation takes place. On the other hand, oxygen transport through the aerenchyma to the rhizosphere may inhibit $\mathrm{CH}_{4}$ production (Whalen and Reeburgh, 2000; Fritz et al., 2011) and stimulate $\mathrm{CH}_{4}$ oxidation (King, 1994; Popp et al., 2000). The net effect of the presence of aerenchymatous species on $\mathrm{CH}_{4}$ fluxes is positive in most cases (Bellisario et al., 1999; Greenup et al., 2000; Rinnan et al., 2003; Couwenberg and Fritz, 2012; Ward et al., 2013), although opposite results have also been reported (Roura-Carol and Freeman, 1999; Strack et al., 2006). Although the influence of the non-aerenchymatous species on the fluxes has been studied relatively little, Gray et al. (2013) showed that plant functional groups based on more complex traits than those related to aerenchyma were good proxies of $\mathrm{CH}_{4}$ flux. In open boreal peatlands, the most abundant non-aerenchymatous vascular plant functional group is dwarf shrubs, which are generally shallow rooted (Korrensalo et al., 2018a) and have a negligible $\mathrm{CH}_{4}$ transport capacity (Shannon et al., 1996; Garnet et al., 2005) compared to deep-rooting aerenchymatous species. In plant removal experiments, the presence of shrubs has been shown to decrease $\mathrm{CH}_{4}$ fluxes (Ward et al., 2013; Robroek et al., 2015). Recently, trees have been shown to transport significant amounts of $\mathrm{CH}_{4}$ from soil in certain ecosystems, but so far not in forested boreal peatlands (Covey and Megonigal, 2019). Sphagnum mosses, in turn, have an impact on $\mathrm{CH}_{4}$ oxidation as they host partly endophytic methanotrophs in the water-filled, hyaline cells of their leaves and stem (Raghoebarsing et al., 2005; Larmola et al., 2010; Putkinen et al., 2012).

Water level regulates the volume ratio of the aerobic and anaerobic peat and, consequently, the extent of the $\mathrm{CH}_{4}$ production and oxidation zones. Therefore, a positive correlation between the water level and $\mathrm{CH}_{4}$ fluxes has been reported in numerous studies (Moore and Roulet, 1993; Laine et al., 2007a; Pearson et al., 2015; Turetsky et al., 2014; Chimner et al., 2017). However, the relationship between the water level and $\mathrm{CH}_{4}$ fluxes is complex due to the vegetationwater level interaction. Because the plant communities in the wettest habitats are often associated with the sparsest vascular plant cover and lowest productivity (Waddington and Roulet, 2000; Laine et al., 2007b; Riutta et al., 2007b), less substrate for $\mathrm{CH}_{4}$ production is available in those communities. At the dry end of the water level gradient, fewer roots reach the anaerobic layer of the peat (Waddington et al., 1996; Kutzbach et al., 2004). Hence, $\mathrm{CH}_{4}$ fluxes may also show a unimodal relationship to water level (Strack et al.,
2004; Brown et al., 2014) or no relationship at all (Rask et al., 2002; Korrensalo et al., 2018b).

In this study, we aim to disentangle the intertwined relationships among water level, vegetation, and fen $\mathrm{CH}_{4}$ fluxes. We test the role assumed for different plant functional groups based on earlier literature and quantify how these roles are modulated by changing water level. Our objective is to quantify the contribution of the different components of fen plant community, namely sedges, dwarf shrubs, Sphagnum mosses, and the underlying peat, to the $\mathrm{CH}_{4}$ fluxes under wet and dry conditions. To achieve this, we applied removal treatments of plant functional groups under both natural and experimentally lowered water level in a factorial study design. We hypothesized that aerenchymatous plant species enhance $\mathrm{CH}_{4}$ fluxes and that this effect would be less pronounced under lowered water level as a smaller proportion of the roots would extend to the anaerobic peat layer. Further, we hypothesized Sphagnum mosses and dwarf shrubs to reduce $\mathrm{CH}_{4}$ fluxes.

\section{Materials and methods}

\subsection{Study site}

The study was carried out at Lakkasuo peatland complex, an eccentric raised bog with minerotrophic laggs situated in the southern boreal vegetation zone (Ahti et al., 1968) in southern Finland $\left(61^{\circ} 47^{\prime} \mathrm{N}, 24^{\circ} 18^{\prime} \mathrm{E}\right)$. Annual precipitation in the region totals $710 \mathrm{~mm}$, of which about a third falls as snow. The average temperatures for January and July are -8.9 and $15.3^{\circ} \mathrm{C}$, respectively (Juupajoki Hyytiälä weather station).

The study site was situated on a nutrient-poor, oligotrophic, treeless fen part of the peatland complex. Surface topography at the site is uniform, mostly lawn. The $\mathrm{pH}$ of the surface peat at the site was 4.9 (Juottonen et al., 2005). The field layer is dominated by sedges and dwarf shrubs. The most abundant sedge species is Carex lasiocarpa Ehrh. (percentage of cover in $20013.4 \pm 3.9$, mean \pm standard deviation of 40 inventory plots), and other common sedge species are Eriophorum vaginatum L. $(0.9 \pm 1.8)$ and Trichophorum cespitosum (L.) Hartm. $(0.5 \pm 2.4)$. The most abundant shrubs are the deciduous Betula nana L. (4.0 \pm 4.2$)$ and ericaceous Andromeda polifolia L. $(6.6 \pm 5.7)$ and Vaccinium oxycoc$\cos \mathrm{L}$. $(4.9 \pm 4.2)$. Note that due to the erect growth form of sedges, their percentage of cover is lower than that of shrubs, although their leaf area is higher; see Table 1 and Fig. 2. The moss layer forms a continuous carpet dominated by Sphagnum papillosum Lindb. (40.1 \pm 31.3$)$ and the species of the $S$. recurvum complex (S. fallax (Klinggr.) Klinggr., S. flexuosum Dozy \& Molk, and S. angustifolium (C.E.O.Jensen ex Russow) C.E.O.Jensen) (together $32.7 \pm 24.0$ ). The vegetation inventory and variation conducted at the site are described in detail in Kokkonen et al. (2019). 
Table 1. Growing season average (standard deviation) water level (WL) relative to moss surface (in centimeters), with negative values indicating water level below the surface, growing season peak LAI of sedges $\left(\mathrm{LAI}_{\mathrm{C}}\right)$ and dwarf shrubs $\left(\mathrm{LAI} \mathrm{I}_{\mathrm{D}}\right)$, and projection cover of Sphagnum mosses (Spha) (unit is square meters per square meter) in different plant removal treatments in wet and WL drawdown subsites. The year 2001 was a calibration year without the WL drawdown and plant removal treatments, which were implemented in 2002 . Vegetation treatments: PSCD - plots with intact vegetation, consisting of peat, Sphagnum mosses, sedges, and shrubs; PSC - plots consisting of peat, Sphagnum mosses, and sedges (shrubs removed); PS - plots consisting of peat and Sphagnum mosses (shrubs and sedges removed); P - plots consisting of bare peat (all vegetation removed).

\begin{tabular}{llrrrr|rrrr}
\hline Year & Vegetation & \multicolumn{4}{c|}{ Wet } & \multicolumn{4}{c}{ WL drawdown } \\
\cline { 3 - 9 } & & WL & LAI $_{C}$ & LAI $_{D}$ & Spha & WL & LAI $_{C}$ & LAI $_{D}$ & Spha \\
\hline 2001 & PSCD & $-7(4)$ & $0.7(0.3)$ & $0.2(0.1)$ & $0.8(0.2)$ & $-5(3)$ & $0.7(0.3)$ & $0.3(0.2)$ & $0.8(0.1)$ \\
2004 & PSCD & $-10(4)$ & $0.6(0.2)$ & $0.3(0.1)$ & $0.9(0.1)$ & $-24(6)$ & $0.3(0.1)$ & $0.3(0.1)$ & $0.6(0.2)$ \\
& PSC & $-10(5)$ & $0.7(0.5)$ & & $0.7(0.2)$ & $-29(7)$ & $0.8(0.3)$ & & $0.7(0.3)$ \\
& PS & $-11(3)$ & & & $0.8(0.2)$ & $-26(7)$ & & & $0.7(0.2)$ \\
P & $-7(4)$ & & & & $-21(8)$ & & & \\
\hline
\end{tabular}

\subsection{Experimental design}

The study was carried out during four growing seasons from 2001 to 2004. The first season of the study, 2001, served as a calibration year without the water level drawdown (WLD) treatment, which was implemented in April 2002. The study site was divided into two subsites approximately $20 \mathrm{~m}$ apart, namely the wet and the drier WLD subsite, by surrounding the WLD subsite with a shallow ditch that lowered the water level by an average $17 \pm 1.6 \mathrm{~cm}(22 \pm 3.0 \mathrm{~cm}$ in $2002,12 \pm$ $3.4 \mathrm{~cm}$ in 2003 , and $16 \pm 1.9 \mathrm{~cm}$ in 2004). The shallow ditch was located approximately $10 \mathrm{~m}$ from the wet subsite and drained to a larger, old ditch.

We studied the contribution of the ecosystem components to the net $\mathrm{CH}_{4}$ fluxes in wet and dry conditions by means of plant removal treatments. At the site, we established permanent sample plots of $56 \mathrm{~cm} \times 56 \mathrm{~cm}$ consisting of

- peat, Sphagnum mosses, sedges, and dwarf shrubs (PSCD, intact vegetation, $n=8$ at the wet subsite and $n=8$ at the WLD subsite)

- peat, Sphagnum mosses, and sedges (PSC, dwarf shrubs removed, $n=5+4$ )

- peat and Sphagnum mosses (PS, sedges, and shrubs removed, $n=3+3$ )

- peat ( $\mathrm{P}$, all vegetation removed, $n=4+4)$.

The plant removal treatment plots (PSC, PS, and P) were established April 2002. In the plant removal treatment plots vascular plants were cut with scissors to the level of the moss (PS plots) or peat (P plots) surface and their aboveground litter was removed. In the P plots the top $1.5 \mathrm{~cm}$ of the Sphagnum moss carpet was cut off with scissors. All emerging regrowth was clipped off once a week as necessary. Over the course of the study, progressively less clipping was needed, with hardly any in 2004. Prior to $\mathrm{CH}_{4}$ flux measurements, sedge stubble in P and PS plots was treated with paraffin wax to seal the aerenchymatous pathway of $\mathrm{CH}_{4}$.

\subsection{Measurements}

$\mathrm{CH}_{4}$ fluxes were measured using the closed-chamber method. A stainless steel collar $(56 \mathrm{~cm} \times 56 \mathrm{~cm} \times 30 \mathrm{~cm}$, length $\times$ width $\times$ height) was permanently inserted into each sample plot prior to the start of the study. The collars had a water groove to allow chamber placement and airtight sealing during the measurement. For the flux measurements, an aluminum chamber of $60 \mathrm{~cm} \times 60 \mathrm{~cm} \times 30 \mathrm{~cm}$ was placed on the water groove of the collar. After the chamber placement, a vent on the chamber roof that ensured pressure equilibration was sealed with a septum plug. A battery-operated fan circulated the air inside the chamber. A $40 \mathrm{~mL}$ air sample was drawn into a polypropylene syringe at $5,15,25$, and $35 \mathrm{~min}$ after closure. The samples were stored at $+4^{\circ} \mathrm{C}$ before analysis, which was carried out within $36 \mathrm{~h}$. Samples were analyzed with a HP-5710A gas chromatograph (GC) from 2001 to 2003 and with a HP-5890A GC in 2004. Both GCs were equipped with a $1 \mathrm{~mL}$ loop, $6 \times 1 / 8^{\prime \prime}$ packed column (HayeSep Q in HP-5710A; Porapak Q in HP-5890A) and flame ionization detector. The carrier gas was helium with a flow rate of $30 \mathrm{~mL} \mathrm{~min}^{-1}$. Column and detector temperatures were 40 and $300{ }^{\circ} \mathrm{C}$, respectively. The precision of the analysis was $\pm 0.16 \%$, determined as the coefficient of variation of the replicate samples.

To relate the fluxes to prevailing environmental conditions, peat temperatures at $5,10,20$, and $30 \mathrm{~cm}$ below the moss surface and water level in a perforated tube adjacent to each plot were measured during the flux measurements. Air and peat temperatures and precipitation were also continuously recorded at the weather station at the site. Green leaf area index (LAI) of each vascular plant species in each plot was determined with the method of Wilson et al. (2007) from April until November, as a product of the total number of leaves (counted monthly) and the average leaf size of marked indi- 
viduals (measured every 2 weeks). Species-specific Gaussian curves (Wilson et al., 2007) were fitted to the observations to describe the continuous development of LAI throughout the season. LAI of different species was summed up to sedge, dwarf-shrub, and total $\mathrm{LAI}\left(\mathrm{LAI}_{\mathrm{C}}, \mathrm{LAI}_{\mathrm{D}}\right.$, and $\mathrm{LAI}_{\mathrm{T}}$, respectively). Moss cover at each plot was visually estimated annually.

In addition to $\mathrm{CH}_{4}$ exchange, $\mathrm{CO}_{2}$ exchange was measured at the study site. The methods and results are reported elsewhere (Riutta et al., 2007a) in more detail, but some $\mathrm{CO}_{2}$ exchange estimates are used here to study the relationship between the $\mathrm{CO}_{2}$ and $\mathrm{CH}_{4}$ fluxes. In summary, net ecosystem $\mathrm{CO}_{2}$ exchange (NEE) was measured weekly or once every 2 weeks by employing the closed-chamber technique in the same plots and during the same period as the $\mathrm{CH}_{4}$ fluxes. Measurements were carried out in both light and dark, which enabled the partitioning of the fluxes into gross photosynthesis and ecosystem respiration. We constructed nonlinear regression models for photosynthesis and respiration, with water level, temperature, and LAI as explanatory factors, separately for each vegetation treatment, to reconstruct the fluxes for the whole growing season.

\subsection{Data analyses}

$\mathrm{CH}_{4}$ flux was calculated as the linear change in $\mathrm{CH}_{4}$ concentration as a function of time by fitting a least-squares regression line. Of the 1300 measurements, $<0.5 \%$ were rejected due to clear errors, such as leakage or problems in the GC analysis, and $2 \%$ were classified as episodic fluxes.

To reconstruct seasonal (June-September) estimates for each sample plot, the fluxes measured once every 2 weeks were linearly interpolated between measurement days, and the obtained daily values were integrated. In the interpolation, rejected values and episodic fluxes were replaced with the median flux of the corresponding vegetation and water level treatment on the same measurement day. The impact of the episodic fluxes on the seasonal flux was taken into account by using the episodic values as the $\mathrm{CH}_{4}$ flux estimates of the day they were measured. The reconstructed seasonal fluxes at the wet and WLD subsites were converted to $\mathrm{CO}_{2}$ equivalent according to Myhre et al. (2013).

We used linear mixed-effect models to test the impact of the plant removal treatments and the WLD treatment on WL, LAI, and daily measured $\mathrm{CH}_{4}$ flux. First, we tested the differences in $\mathrm{WL}, \mathrm{LAI}_{\mathrm{C}}, \mathrm{LAI}_{\mathrm{D}}, \mathrm{LAI}_{\mathrm{T}}$, and $\mathrm{CH}_{4}$ flux between the wet and WLD subsites before the WLD treatment was applied (year 2001) and over the years after the WLD treatment (2002-2004), with WLD treatment, year, and their interaction as potential fixed predictors. This model included only the plots with intact vegetation (PSCD). The wet subsite in 2001 was the constant against which WLD and other years were compared. Therefore, the difference between the wet and WLD treatment in the model describes the pretreatment difference among the two subsites in the calibra- tion year 2001, and the interaction between WLD treatment and the years 2002-2004 describes the impact of WLD after the treatment.

Second, we tested the impact of plant removal on $\mathrm{CH}_{4}$ flux over the years and the interaction of the plant removal treatments with the WLD treatment with data from the years 2002 to 2004 (no plant removal treatments in 2001). For each year separately, we fitted a model with plant removal treatments, WLD treatment, and the interaction between them as potential fixed predictors.

Third, we tested the response of $\mathrm{CH}_{4}$ flux to leaf area and environmental variables by extending the model fitted to the data of the year 2004, which had the maximum amount of time for stabilization after the treatments. In addition to plant removal and WLD treatments, potential fixed predictors were $\mathrm{LAI}_{\mathrm{C}}, \mathrm{LAI}_{\mathrm{D}}$, cover of Sphagnum mosses, measured $\mathrm{WL}$, temperature in the chamber, and peat temperature at the depths of 5, 10, 20, and $30 \mathrm{~cm}\left(T_{5}, T_{10}, T_{20}\right.$, and $\left.T_{30}\right)$ as well as the potential interactions among these parameters. Potential new predictors were sequentially added and after each addition the significance of all predictors was tested. We reported both models separately for the year 2004: one including plant removal and WLD treatments as fixed predictors for $\mathrm{CH}_{4}$ flux and another including the response of $\mathrm{CH}_{4}$ flux to leaf area and cover of plant groups and environmental variables.

In each case, a conditional $F$ test was used to test if the full model with all fixed predictors and their interactions was significantly better $(p<0.05)$ than a simpler model. Plot and date were included as crossed random effects. Resulting models are reported in Table 2. The models were fitted using the function lmer of the package lme4 (Bates et al., 2015) of RStudio version 1.1.383.

\section{Results}

\subsection{Impact of the water level drawdown}

The pre-treatment water level did not differ between the wet and WLD subsites ( $p=0.174$, comparison between wet and WLD treatment during the calibration year 2001) (Fig. 1a, Table 1). Following the drainage in April 2002, the water level was significantly lower in the WLD subsite $(p<0.001$, interaction between WLD and the year 2002). The WLD treatment lowered the water level by approximately $17 \mathrm{~cm}$, except in July and August 2003 when a severe drought lowered the water level below the ditch, resulting in similar water levels at wet and WLD subsites. At the wet subsite, the water level during the years 2001 and 2004 was similar to the longterm average of the site, approximately 5 to $10 \mathrm{~cm}$ below the moss surface (Table 1) (Laine et al., 2004). During July and August 2002 and 2003, however, the water level was lower than the long-term average. More information on the weather conditions during the study is given in Riutta et al. (2007b). 


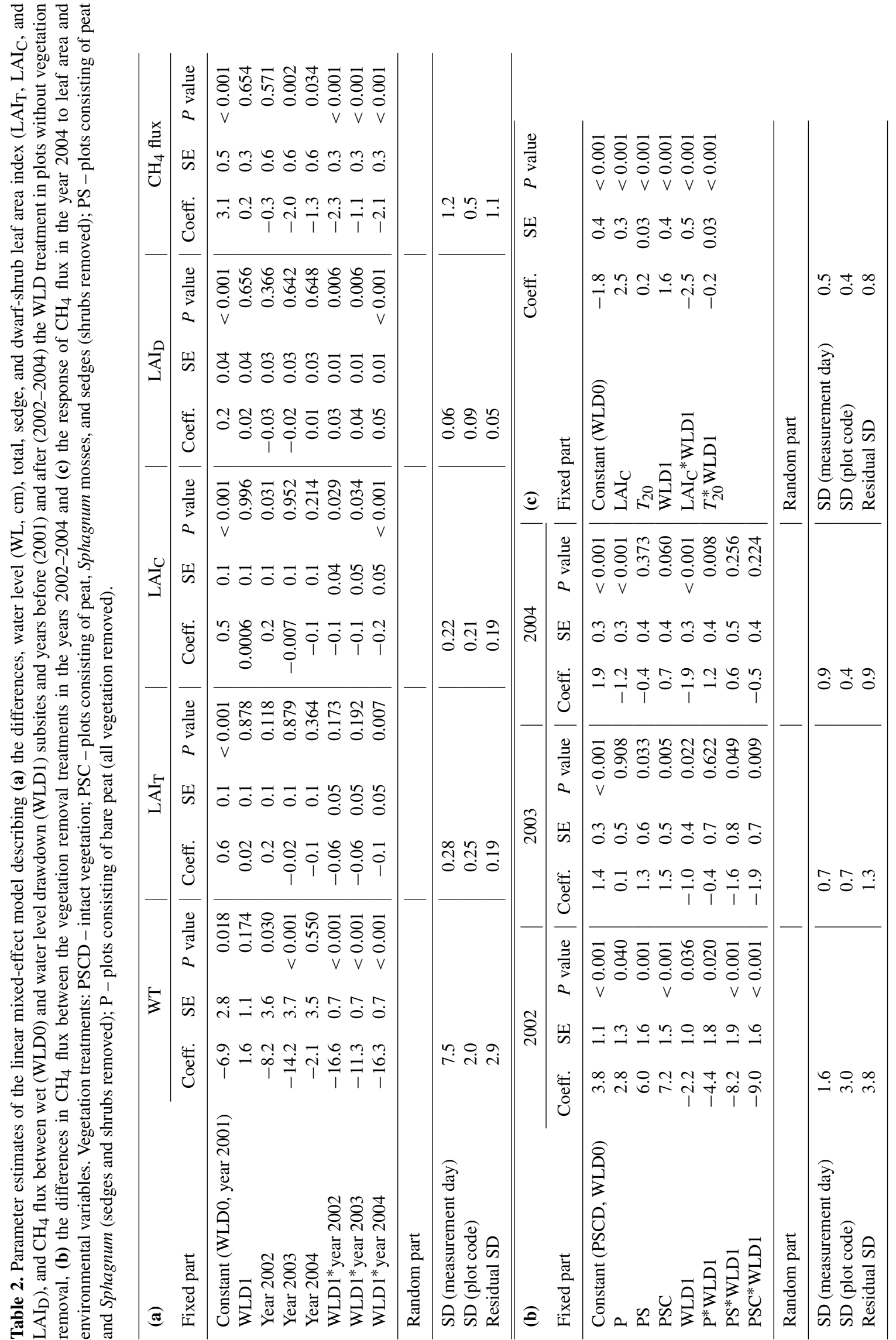



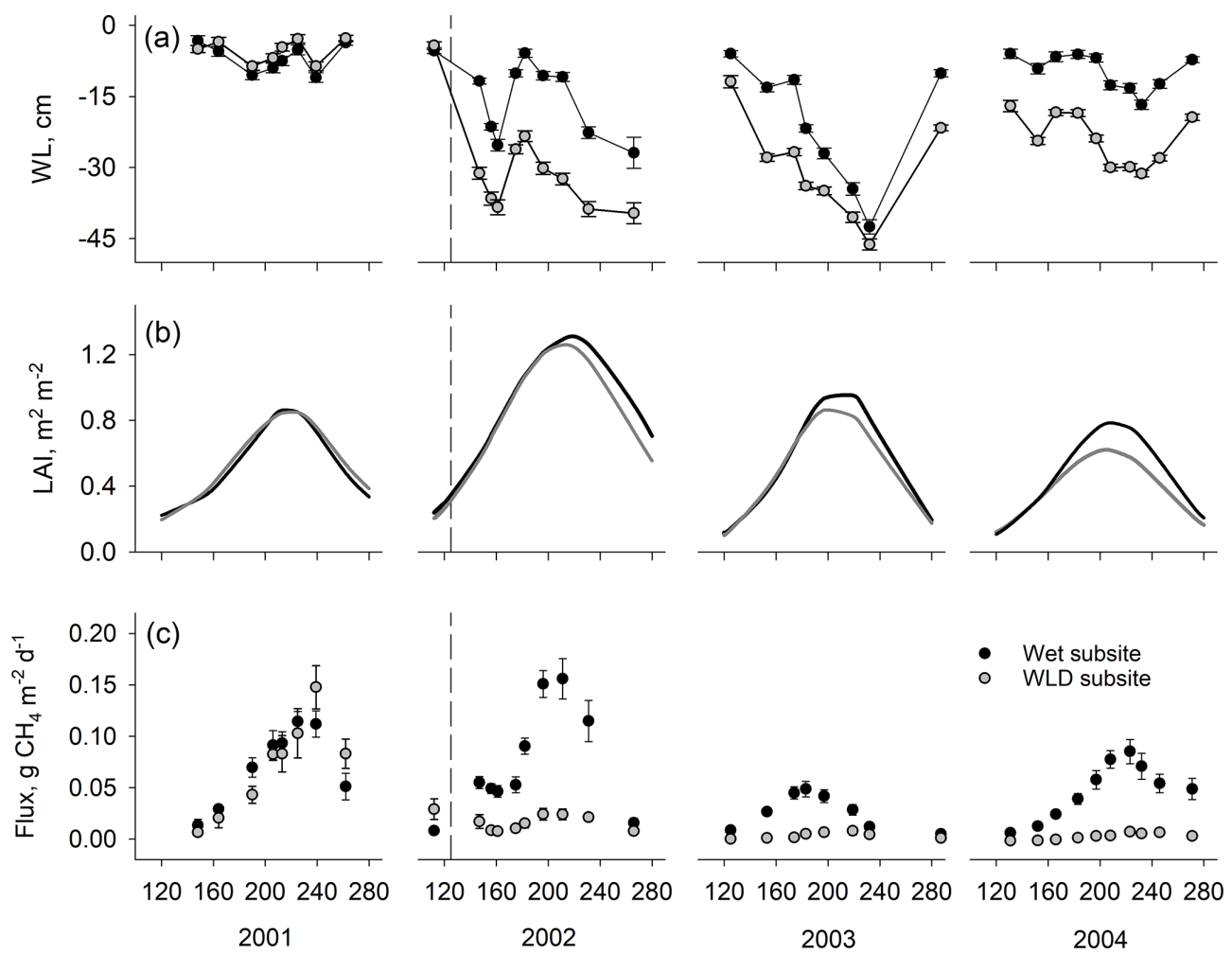

Figure 1. Mean (a) water level (WL), (b) leaf area index (LAI), and (c) $\mathrm{CH}_{4}$ flux in plots with intact vegetation at wet and water level drawdown (WLD) subsites. Error bars are standard errors of the mean. Units on the $x$ axis give the day of year. The start of the water level drawdown treatment is indicated with the vertical dashed line in 2002. Water level is negative when it is below the moss surface. Positive $\mathrm{CH}_{4}$ fluxes indicate emission to the atmosphere.

Prior to the drainage, vegetation composition in the plots with intact vegetation (PSCD) was similar at both subsites (Table 1, Fig. 1b). In the mixed-effect model, $\mathrm{LAI}_{\mathrm{C}}, \mathrm{LAI}_{\mathrm{D}}$, and $\mathrm{LAI}_{\mathrm{T}}$ did not differ between wet and WLD subsites in the year 2001 ( $p$ values $0.996,0.656$, and 0.878 , respectively). In 2001 the peak season average $\mathrm{LAI}_{\mathrm{T}}$ was approximately $1.0 \mathrm{~m}^{2} \mathrm{~m}^{-2}$, of which sedges composed $70 \%$. The mean Sphagnum cover was $80 \%$. By the third year since WLD, $2004 \mathrm{LAI}_{\mathrm{C}}$ had decreased $(p<0.001)$ and $\mathrm{LAI}_{\mathrm{D}}$ increased $(p<0.001)$ at the WLD subsite, resulting in an overall decrease in $\mathrm{LAI}_{\mathrm{T}}(p=0.007)$ (Table 1, Fig. 1b).

In the PSCD plots, the pre-treatment $\mathrm{CH}_{4}$ fluxes did not differ between the wet and WLD subsites $(p=0.654)$ (Fig. 1c). After the treatment, in 2002-2004, fluxes were significantly lower in the WLD than at the wet subsite $(p<$ 0.001 for all years). During the 3-year WLD treatment, the mean flux was approximately 51 and $7.0 \mathrm{mg} \mathrm{CH}_{4} \mathrm{~m}^{-2} \mathrm{~d}^{-1}$ at the wet and WLD subsites, respectively. Converted to $\mathrm{CO}_{2}$ equivalents, the seasonal reconstructed fluxes at the wet and WLD subsites in 2002-2004 were 236 and $32 \mathrm{~g} \mathrm{CO}_{2}$ eq. $\mathrm{m}^{-2}$ per growing season, respectively.

\subsection{Impact of the plant removal treatments}

Plant removal treatments did not lead to major changes in vegetation composition beyond the clipped target groups. Vascular plant removal did not affect the Sphagnum moss cover, and the removal of dwarf shrubs did not change the LAI of sedges. LAI $_{C}$ was similar in PSC and PSCD plots (data for 2004 shown in Table 1) during all years at the wet subsite and during 2003 and 2004 at the WLD subsite (all $p$ values $>0.05)$. LAI $_{C}$ was higher in the PSC plots than in the PSCD plots at the WLD subsite in 2002 ( $p=0.016)$.

During the first season of the removal treatments (2002) at the wet subsite, $\mathrm{CH}_{4}$ fluxes were higher in the plant removal plots (P, PS, and PSC) than in the intact plots (PSCD), in some cases almost triple $(p<0.05$ for all treatments, Fig. 2a-c). The fluxes in the plant removal treatment plots also showed a stronger seasonal pattern and larger spatial variation. After the first year of removal treatments, the fluxes of the P, PS, and PSC plots decreased, and in 2003 P plots had a similar $\mathrm{CH}_{4}$ flux to the intact plots $(p=0.908)$, while PS and PSC plots still had a higher flux than PSCD plots ( $p=0.033$ and $p=0.005$, respectively).

By the third year of the plant removal treatments (2004), the fluxes in all treatments showed a seasonal pattern sim- 
ilar to that of the intact plots. Bare peat plots had lower fluxes than the intact PSCD plots $(p<0.001)$. Fluxes of the PSC plots (shrubs removed) were marginally significantly higher $(p=0.060)$ than those of the PSCD plots (shrubs present). In WLD conditions, the fluxes in the plant removal plots (P, PS, and PSC) were mostly lower than the fluxes in the intact PSCD plots during all three vegetation treatment years (Fig. 2d-f), but the differences were not significant (Table $2 b)$. WLD and plant removal treatments had a significant interaction: in 2004 WLD lowered the fluxes more in PSCD plots than in the P plots and more in PSC plots than in the $\mathrm{P}$ and PS plots ( $p<0.05$ for the interaction terms). Seasonal fluxes visualize the patterns tested with the nonlinear mixedeffect models: at the WLD subsite fluxes were lower than at the wet subsite in all plant removal treatments (Fig. 3b). In wet conditions, the seasonal flux of the P and PS plots was lower than that of the PSCD and PSC plots in which vascular plants were present (Fig. 3a). Taking the fluxes from bare peat plots as a baseline, the presence of vegetation enhanced the fluxes. Compared with the situation of sedges and Sphagna present (PSC), the presence of shrubs (PSCD) seemed to slightly attenuate the fluxes (Fig. 3b, c). In WLD conditions, the differences between plant removal treatments were negligible. The differences between the plant removal treatments can be used as an estimate of the contribution of each plant group to the total flux, although due to the propagation of the errors, uncertainty in these estimates is large. In normal hydrological conditions, plant-mediated flux accounted for $68 \% \pm 23 \%$ (comparison of $\mathrm{P}$ and PSCD plots) or $78 \% \pm 17 \%$ (comparison of P and PSC plots) of the total growing season flux, of which Sphagnum mosses and sedges accounted for approximately one-fourth and three-fourths, respectively (Fig. 3c).

The seasonal $\mathrm{CH}_{4}$ fluxes displayed a clear positive, exponential relationship with the seasonal net $\mathrm{CO}_{2}$ flux (Fig. 4). The relationship was similar among the plant removal treatments in wet and dry conditions. However, the plots with intact vegetation (PSCD) were an exception; they had lower $\mathrm{CH}_{4}$ fluxes than could have been expected based on their net $\mathrm{CO}_{2}$ flux, pointing towards the potential suppressing effect of shrubs on $\mathrm{CH}_{4}$ emissions.

\subsection{Response of $\mathrm{CH}_{4}$ flux to environmental variables and interaction with leaf area}

The best predictors of the $\mathrm{CH}_{4}$ flux in the extended model for the year 2004 were the categorical WLD treatment (which was a better predictor than the measured WL), $T_{20}$ (best out of the measured temperatures), and $\mathrm{LAI}_{\mathrm{C}}$ (which was a better predictor than the categorical vegetation removal treatment). The abundance of the other plant functional groups, $\mathrm{LAI}_{\mathrm{D}}$, or Sphagnum cover did not have a significant effect on the fluxes. $\mathrm{CH}_{4}$ flux was increased by $\mathrm{LAI}_{\mathrm{C}}$ and $T_{20}$ in wet conditions (Table 2c). In the WLD conditions, however, neither LAI $_{C}$ nor $T_{20}$ had any impact on the fluxes (coefficient esti- mates for $\mathrm{LAI}_{\mathrm{C}}{ }^{*} \mathrm{WLD} 1$ and $T_{20}^{*} \mathrm{WLD} 1$ cancel out the coefficient estimates for $\mathrm{LAI}_{\mathrm{C}}$ and $T_{20}$ in wet conditions; Table $2 \mathrm{c}$ ). The positive coefficient of the WLD treatment seemingly indicated a larger flux at the WLD treatment site compared with the wet site, when $\mathrm{LAI}_{\mathrm{C}}$ and $T_{20}$ both equal zero; however, the measured minimum $T_{20}$ during the growing season in 2004 was $6.1^{\circ} \mathrm{C}$, and the model was not intended for any extrapolation. The predicted $\mathrm{CH}_{4}$ flux in the WLD treatment was similar to or lower than the flux in the wet treatment in the observed $T_{20}$ and $\mathrm{LAI}_{\mathrm{C}}$ range.

\section{Discussion}

\subsection{The effect of the plant types and substrate on the $\mathrm{CH}_{4}$ fluxes in natural water level conditions}

In line with previous studies, the plant removal treatments of this study indicated that sedges were the most important plant group in regulating $\mathrm{CH}_{4}$ fluxes. In other sedge-dominated sites, plant-mediated flux has accounted for $75 \%$ to $97 \%$ of the total flux (Schimel, 1995; Kelker and Chanton, 1997; Ström et al., 2005; Sun et al., 2012; Noyce et al., 2014) and plant removal experiments have shown that of different plant functional types, removal of graminoids causes the largest decrease in $\mathrm{CH}_{4}$ production and flux (Ward et al., 2013; Robroek et al., 2015). Compared with the bare peat surfaces, the presence of Sphagnum mosses seemed to have a slight, although not statistically significant, enhancing effect on the $\mathrm{CH}_{4}$ fluxes, similar to the results of Roura-Carol and Freeman (1998), who found the presence of mosses to have a slightly attenuating effect on the fluxes, while Greenup et al. (2000) did not find significant differences in fluxes after Sphagnum removal. Based on this, the $\mathrm{CH}_{4}$ oxidation by the loosely symbiotic methanotrophs within Sphagnum mosses (Raghoebarsing et al., 2005; Larmola et al., 2010; Putkinen et al., 2012) seems to play a minor role in $\mathrm{CH}_{4}$ dynamics at our site.

Similarly to Ward et al. (2013), we found that the presence of shrubs seemed to have a slightly attenuating effect on the fluxes under natural water level conditions. Robroek et al. (2015) made a similar finding with potential $\mathrm{CH}_{4}$ production. In contrast, an aerenchymatous shrub, Myrica gale, supported similar potential $\mathrm{CH}_{4}$ production to a sedge, Carex aquatilis, and did not suppress $\mathrm{CH}_{4}$ flux (Strack et al., 2017). Furthermore, in line with the attenuating effect of shrubs, the $\mathrm{CH}_{4}$ flux : NEE ratio was lower in the plots with intact vegetation (PSCD, shrubs present) than in the other vegetation treatments. Mechanisms behind that might relate to the impact of shrubs on soil chemistry, microbial community, or the biomass allocation of sedges. Shrub litter has higher lignin and leaf dry matter content than sedges, which are both related to lower methanogenesis (Yavitt et al., 2019). Shrub removal has been observed to result in higher dissolved organic $\mathrm{C}$ and $\mathrm{N}$ and lower $\mathrm{C}: \mathrm{N}$ ratio (Ward et al., 2013) as 

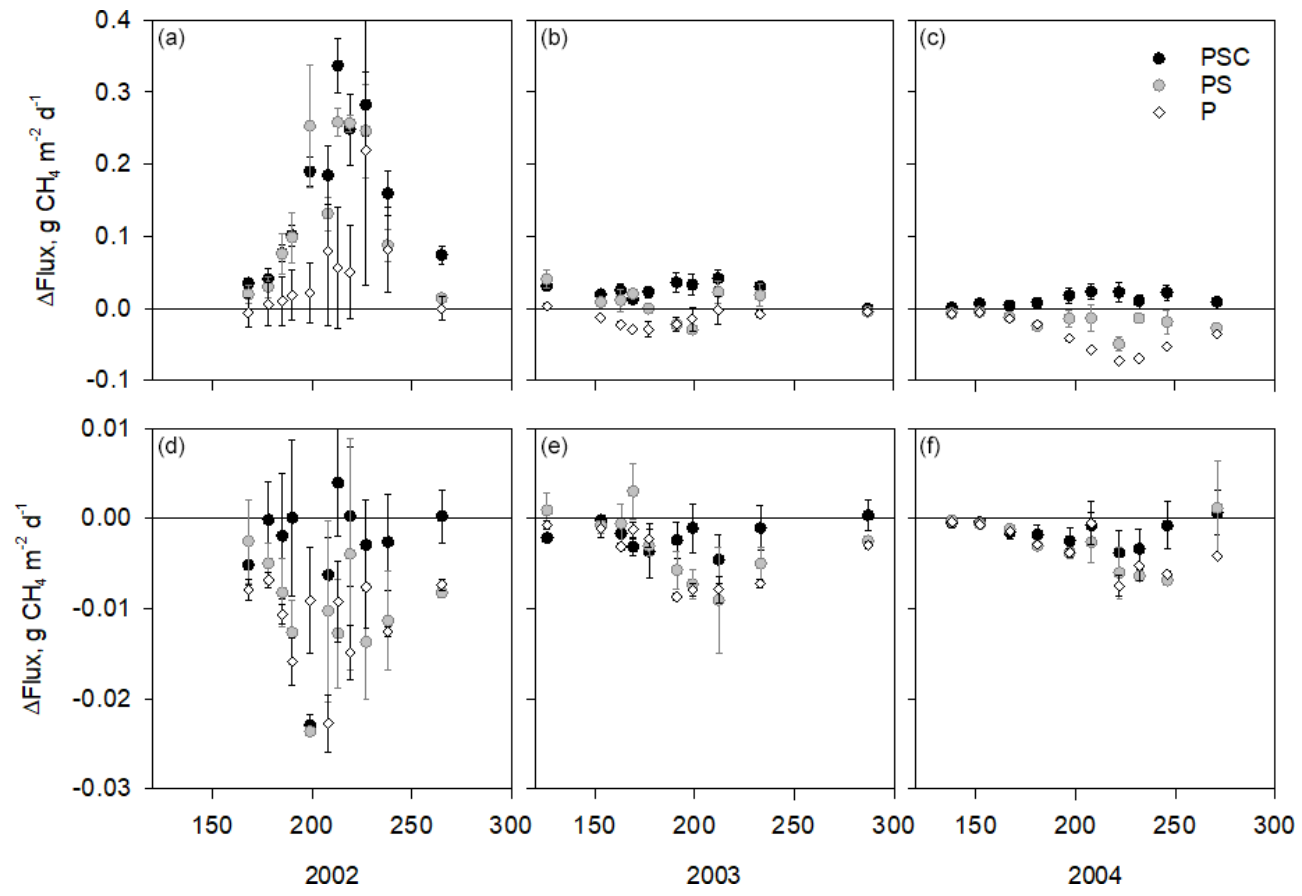

Figure 2. Difference of the measured $\mathrm{CH}_{4}$ fluxes in plots with plant removal treatments and the mean flux in the plots with intact vegetation on each measurement day at the control subsite $(\mathbf{a}, \mathbf{b}, \mathbf{c})$ and water level drawdown subsite $(\mathbf{d}, \mathbf{e}, \mathbf{f})$. Positive values indicate that fluxes in the plant removal treatment plots are higher than in the intact plots. Units on the $x$ axis give the day of year. Note the difference scales of the $y$ axes in the upper and lower panels. Error bars are standard errors of the mean. Vegetation treatments: PSC - plots consisting of peat, Sphagnum mosses, and sedges (shrubs removed); PS - plots consisting of peat and Sphagnum (sedges and shrubs removed); P - plots consisting of bare peat (all vegetation removed). Intact plots consisted of peat, Sphagnum mosses, sedges, and shrubs. Removal treatments were established in 2002.
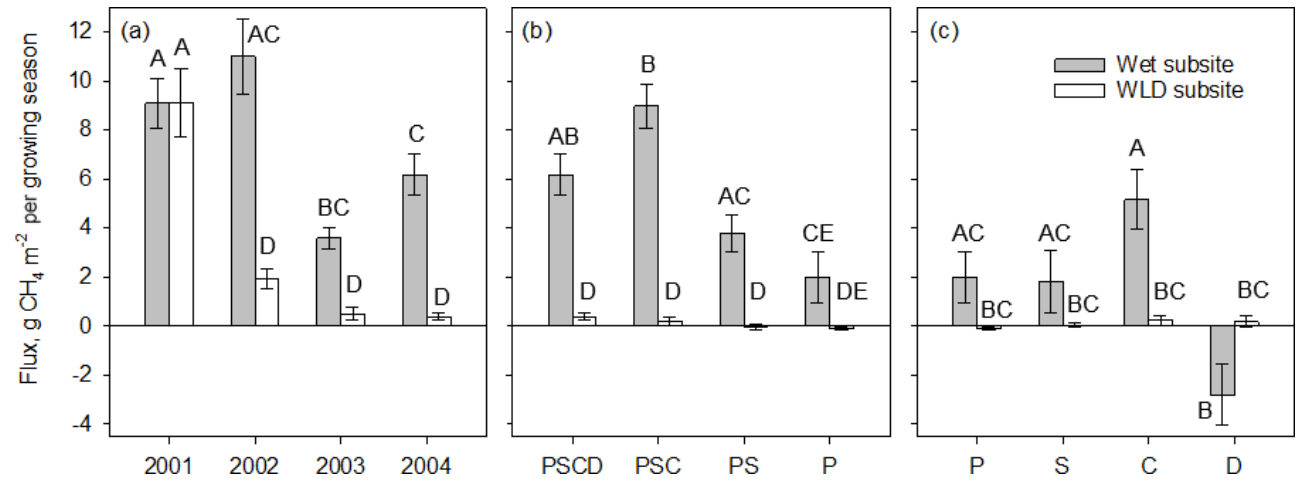

Figure 3. Seasonal (June-September) $\mathrm{CH}_{4}$ flux (mean \pm 1 standard error) at wet and water level (WLD) drawdown subsites (a) in plots with intact vegetation (PSCD) during the 4 study years (2001 was a calibration year before the implementation of the WLD treatment), (b) in different plant removal treatments plots in 2004, and (c) by each plant group, the contribution of which to the total flux in 2004 was estimated from differences between the different plant removal treatments. Letters above bars denote differences among treatments, where bars with no letter in common are significantly different based on a mixed-effect models presented in Table 2 (a, b) and based on two-way ANOVA test with Tukey pairwise comparisons (c). Plant removal treatments in (b): PSCD - plots with intact vegetation, consisting of peat, Sphagnum mosses, sedges, and shrubs; PSC - plots consisting of peat, Sphagnum mosses, and sedges (shrubs removed); PS - plots consisting of peat and Sphagnum mosses (shrubs and sedges removed); $\mathrm{P}$ - plots consisting of bare peat (all vegetation removed). Plant groups in (c): $\mathrm{P}-$ bare peat; $\mathrm{S}$ - Sphagnum mosses; C - sedges; D - dwarf shrubs. 

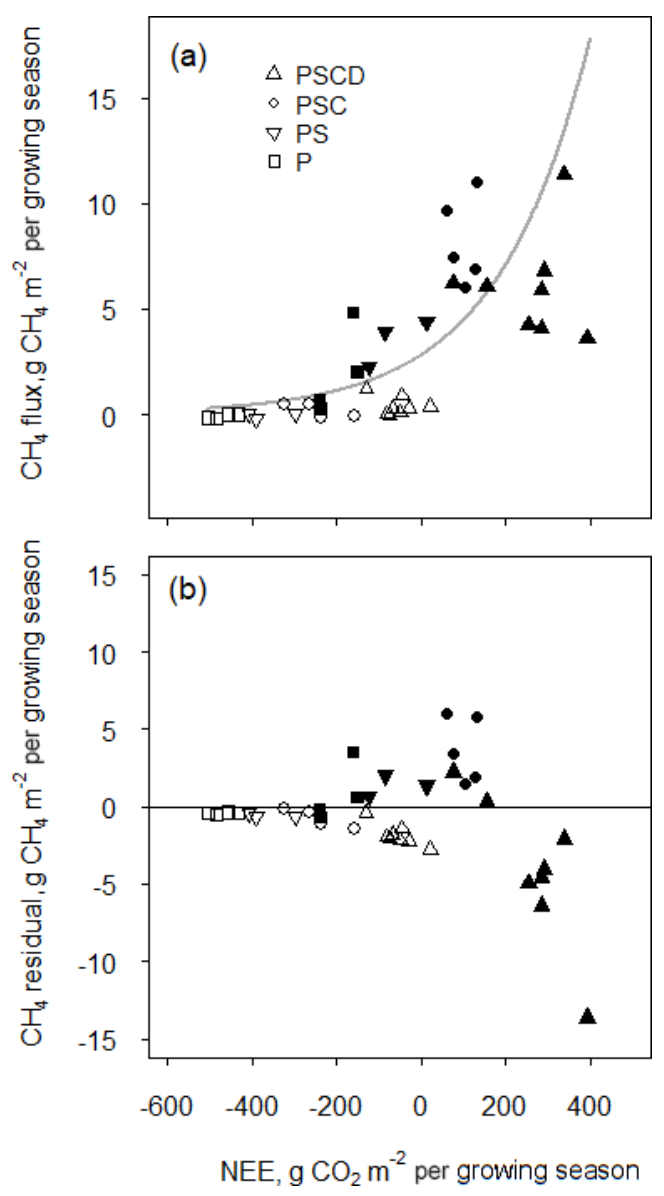

Figure 4. (a) The relationship between the net ecosystem $\mathrm{CO}_{2}$ uptake (NEE) and $\mathrm{CH}_{4}$ flux during the growing season of 2004 described with an exponential model and (b) the residuals of the model, in the different plant removal treatments at wet (solid symbols) and water level drawdown (open symbols) subsites. Vegetation treatments: PSCD - plots with intact vegetation, consisting of peat, Sphagnum mosses, sedges, and shrubs; PSC - plots consisting of peat, Sphagnum mosses, and sedges (shrubs removed); PS plots consisting of peat and Sphagnum mosses (shrubs and sedges removed); $\mathrm{P}$ - plots consisting of bare peat (all vegetation removed). NEE is positive when the fen is a net sink of atmospheric $\mathrm{CO}_{2}$. Methane flux is positive when the fen is a source of $\mathrm{CH}_{4}$ to the atmosphere.

well as higher fungal biomass (Robroek et al., 2015). A study on the competitive ability and biomass allocation of a wetland grass, Molinia caerulea, revealed that $M$. caerulea allocated more biomass to the roots when it did not face competition by shrubs (Aerts et al., 1991). Similarly, in our study, sedges in the plots where shrubs were removed may have allocated more biomass to the roots than the sedges growing in the sedge and shrub mixture. As a result, methanogenic microbes may have benefited from the higher substrate availability in the shrub removal plots (PSC). $\mathrm{CH}_{4}$ production has a negative relationship and $\mathrm{CH}_{4}$ oxidation has a positive relationship with the concentration of certain woody lignin com- pounds in peat pore water (Yavitt et al., 2000). In our study, this may be the reason behind the lower fluxes in the presence of the arboreals. The results concerning the attenuating effect of shrubs on $\mathrm{CH}_{4}$ fluxes are, however, only indicative and further process-orientated research is needed.

\subsection{Delay in the plant removal treatment effect}

We observed a considerable disturbance in the fluxes following the plant removal treatments. In other clipping studies in which the shoots were cut above the water level, clipping increased the $\mathrm{CH}_{4}$ flux during the first growing season after clipping (Schimel, 1995), had no effect (Kelker and Chanton, 1997; Greenup et al., 2000), or decreased the flux (Waddington et al., 1996; Rinnan et al., 2003). Thus, we assumed that the higher fluxes at the clipped plots during the first 2 years after the vegetation removal treatments were mainly caused by treatment artifacts. The removal of the aboveground parts of vascular plants led to the gradual death of the belowground parts, creation of an unnatural amount of new root necromass, and, thereby, a peak in the amount of available substrate. Methanogenesis at the study site may have been substrate limited (Bergman et al., 1998; Rinne et al., 2007), which could explain the initially high fluxes in the plant removal plots. The mass loss of Carex roots and rhizomes is only $10 \%$ to $45 \%$ during the first 12 months of decomposition, although the litter quality deteriorates (Scheffer and Aerts, 2000). However, after 2 years the mass loss can be as much as $75 \%$ of the original mass (Thormann et al., 2001), which gives more confidence in the results of the third year of the plant removal treatments. Thus, we used the third year of the plant removal treatments to quantify the contribution of the vegetation components to the fluxes and the response of fluxes to environmental conditions. King et al. (1998) likewise reported the effects of the plant removal 2 years after the treatment began. Shrub litter, especially belowground litter, decomposes slower than sedge litter (Moore et al., 2007), due to the high lignin content (Yavitt et al., 2019). On the other hand, the majority of dwarf shrub roots grow in the uppermost $20 \mathrm{~cm}$ peat layer, while sedge roots extend deeper (Korrensalo et al., 2018a; Mäkiranta et al., 2018), causing a larger proportion of dwarf shrub roots to decompose in oxic conditions, thus counteracting the differences in litter quality. Even 2 years after the start of the vegetation removal treatments, some shrub roots still probably remained. However, they were mostly located above the $\mathrm{CH}_{4}$ production zone.

\subsection{Water level regulates the role of the vegetation}

Experimental water level drawdown has been used to mimic climate change impact on northern peatland $\mathrm{CH}_{4}$ fluxes in the mesocosm (Freeman et al., 1992; Blodau et al., 2004; Dinsmore et al., 2009) and in the field studies ranging from bogs to rich fens (Laine et al., 2007a; Strack and Waddington, 2007; Turetsky et al., 2008; Ballantyne et al., 2014; Mu- 
nir and Strack, 2014; Pearson et al., 2015; Peltoniemi et al., 2016; Chimner et al., 2017; Olefeldt et al., 2017). In line with our results, all these studies report some level of decrease in $\mathrm{CH}_{4}$ flux due to WLD ranging from 3 to $\sim 20 \mathrm{~cm}$. Together with temperature and vegetation, water level is a major regulator of $\mathrm{CH}_{4}$ flux (Lai, 2009; Turetsky et al., 2014). However, the mechanistic understanding of this process is still limited. While Strack et al. (2004) found only small differences in the $\mathrm{CH}_{4}$ production and consumption potentials between control and WLD sites, and thus attributed the decrease in fluxes mainly to the change in the volume ratio of the anaerobic and aerobic zones, Yrjälä et al. (2011) and Peltoniemi et al. (2016) found that WLD had a stronger impact on emissions through decreasing $\mathrm{CH}_{4}$ production than through increasing oxidation,

In this study, the presence or absence of the plant types or $\mathrm{LAI}_{\mathrm{C}}$ had no effect on the $\mathrm{CH}_{4}$ flux in the WLD conditions. This supports the findings by Waddington et al. (1996) as well as Strack et al. (2006) that the impact of the vegetation on the fluxes is strongly dependent on the water level conditions. $\mathrm{CH}_{4}$ flux also responded to peat temperature only in wet conditions. A similar result with water level and temperature response has been previously reported by Moosavi et al. (1996). Our results showed that water level acts as a switch; it turns $\mathrm{CH}_{4}$ flux on and off, after which temperature and vegetation regulate the flux magnitude. This result is further emphasized by the response model, where WLD treatment including change in the ecosystem following a new WT regime rather than seasonally varying WL was a better predictor for $\mathrm{CH}_{4}$ fluxes. In conclusion, vegetation is a major controlling factor of the peatland $\mathrm{CH}_{4}$ dynamics, but only in wet conditions.

\section{Conclusions}

Vegetation, sedges in particular, regulates the level of fen $\mathrm{CH}_{4}$ fluxes in normal hydrological conditions, but this vegetation control is strongly dependent on the water level regime. In water level drawdown conditions, $\mathrm{CH}_{4}$ fluxes are significantly lowered, practically to zero, and vegetation composition has no influence on the fluxes. The results are relevant for assessing the response of fen peatlands to changing climatic conditions, as water level drawdown and the consequent vegetation changes are the major projected impacts of climate change on northern peatlands.

Data availability. The data associated with the paper are published in the PANGAEA repository (https://doi.pangaea.de/10. 1594/PANGAEA.911742, Riutta et al., 2020a, and https://doi. pangaea.de/10.1594/PANGAEA.911740, Riutta et al., 2020b).

Author contributions. The study was designed and the field experiment established by EST, TR, and JL. Fieldwork, flux calculation, and flux reconstruction was conducted by TR. Statistical analysis was done by AK. TR wrote the first version of the manuscript, which was further processed by all other authors.

Competing interests. The authors declare that they have no conflict of interest.

Acknowledgements. We thank Jouni Meronen for technical support and the field team for assistance in the study site. Meeri Pearson kindly revised the language.

Financial support. This research has been supported by the Academy of Finland (grant nos. 287039, 50707, 201623, and 202424), the Koneen Säätiö, the Jenny ja Antti Wihurin Rahasto, the Faculty of Science and Forestry, University of Eastern Finland, and the Graduate School in Forest Sciences, University of Helsinki.

Review statement. This paper was edited by Alexey V. Eliseev and reviewed by Tariq Munir and one anonymous referee.

\section{References}

Aerts, R., Boot, R. G. A., and van der Aart, P. J. M.: The relation between above- and belowground biomass allocation patterns and competitive ability, Oecologia, 87, 551-559, https://doi.org/10.1007/BF00320419, 1991.

Ahti, T., Hämet-Ahti, L., and Jalas, J.: Vegetation zones and their sections in northwestern Europe, Ann. Bot. Fenn., 5, 169-211, 1968.

Ballantyne, D. M., Hribljan, J. A., Pypker, T. G., and Chimner, R. A.: Long-term water table manipulations alter peatland gaseous carbon fluxes in Northern Michigan, Wetl. Ecol. Manag., 22, 3547, https://doi.org/10.1007/s11273-013-9320-8, 2014.

Bates, D., Mächler, M., Bolker, B., and Walker, S.: Fitting Linear Mixed-Effects Models Using lme4, J. Stat. Softw., 67, 1-48, https://doi.org/10.18637/jss.v067.i01, 2015.

Bellisario, L. M., Bubier, J. L., Moore, T. R., and Chanton, J. P.: Controls on $\mathrm{CH}_{4}$ emissions from a northern peatland, Global Biogeochem. Cy., 13, 81-91, https://doi.org/10.1029/1998GB900021, 1999.

Bergman, I., Svensson, B. H., and Nilsson, M.: Regulation of methane production in a Swedish acid mire by $\mathrm{pH}$, temperature and substrate, Soil Biol. Biochem., 30, 729-741, https://doi.org/10.1016/S0038-0717(97)00181-8, 1998.

Blodau, C., Basiliko, N., and Moore, T. R.: Carbon turnover in peatland mesocosms exposed to different water table levels, Biogeochemistry, 67, 331-351, https://doi.org/10.1023/B:BIOG.0000015788.30164.e2, 2004.

Brown, M. G., Humphreys, E. R., Moore, T. R., Roulet, N. T., and Lafleur, P. M.: Evidence for a nonmonotonic relationship between ecosystem-scale peatland methane emissions and water table depth, J. Geophys. Res.-Biogeo., 119, 826-835, https://doi.org/10.1002/2013JG002576, 2014. 
Chimner, R. A., Pypker, T. G., Hribljan, J. A., Moore, P. A., and Waddington, J. M.: Multi-decadal Changes in Water Table Levels Alter Peatland Carbon Cycling, Ecosystems, 20, 1042-1057, https://doi.org/10.1007/s10021-016-0092-x, 2017.

Christensen, T. R., Friborg, T., Sommerkorn, M., Kaplan, J., Illeris, L., Soegaard, H., Nordstroem, C., and Jonasson, S.: Trace gas exchange in a high-Arctic valley: 1 . Variationsin $\mathrm{CO}_{2}$ and $\mathrm{CH}_{4}$ Flux between tundra vegetation types, Global Biogeochem. Cy., 14, 701-713, https://doi.org/10.1029/1999GB001134, 2000.

Ciais, P., Sabine, C., Bala, G., Bopp, L., Brovkin, V., Canadell, J., Chhabra, A., DeFries, R., Galloway, J., Heimann, M., Jones, C., Le Quéré, C., Myneni, R. B., Piao, S., and Thornton, P.: Carbon and other biogeochemical cycles, in: Climate change 2013: the physical science basis. Contribution of Working Group I to the Fifth Assessment Report of the Intergovernmental Panel on Climate Change, 465-570, Cambridge University Press, 2014.

Couwenberg, J. and Fritz, C.: Towards developing IPCC methane "emission factors" for peatlands (organic soils), Mires Peat, 10, $1-17,2012$.

Covey, K. R. and Megonigal, J. P.: Methane production and emissions in trees and forests, New Phytol., 222, 35-51, https://doi.org/10.1111/nph.15624, 2019.

Ding, W., Cai, Z., and Tsuruta, H.: Diel variation in methane emissions from the stands of Carex lasiocarpa and Deyeuxia angustifolia in a cool temperate freshwater marsh, Atmos. Environ., 38, 181-188, https://doi.org/10.1016/j.atmosenv.2003.09.066, 2004.

Dinsmore, K. J., Skiba, U. M., Billett, M. F., and Rees, R. M.: Effect of water table on greenhouse gas emissions from peatland mesocosms, Plant Soil, 318, 229-242, https://doi.org/10.1007/s11104-008-9832-9, 2009.

Freeman, C., Lock, M. A., and Reynolds, B.: Fluxes of $\mathrm{CO}_{2}, \mathrm{CH}_{4}$ and $\mathrm{N}_{2} \mathrm{O}$ from a Welsh peatland following simulation of water table draw-down: Potential feedback to climatic change, Biogeochemistry, 19, 51-60, https://doi.org/10.1007/BF00000574, 1992.

Fritz, C., Pancotto, V. A., Elzenga, J. T. M., Visser, E. J. W., Grootjans, A. P., Pol, A., Iturraspe, R., Roelofs, J. G. M., and Smolders, A. J. P.: Zero methane emission bogs: extreme rhizosphere oxygenation by cushion plants in Patagonia, New Phytol., 190, 398408, https://doi.org/10.1111/j.1469-8137.2010.03604.x, 2011.

Garnet, K. N., Megonigal, J. P., Litchfield, C., and Taylor, G. E.: Physiological control of leaf methane emission from wetland plants, Aquat. Bot., 81, 141-155, https://doi.org/10.1016/j.aquabot.2004.10.003, 2005.

Gray, A., Levy, P. E., Cooper, M. D. A., Jones, T., Gaiawyn, J., Leeson, S. R., Ward, S. E., Dinsmore, K. J., Drewer, J., Sheppard, L. J., Ostle, N. J., Evans, C. D., Burden, A., and Zieliński, P.: Methane indicator values for peatlands: a comparison of species and functional groups, Glob. Change Biol., 19, 11411150, https://doi.org/10.1111/gcb.12120, 2013.

Greenup, A. L., Bradford, M. A., McNamara, N. P., Ineson, P., and Lee, J. A.: The role of Eriophorum vaginatum in $\mathrm{CH}_{4}$ flux from an ombrotrophic peatland, Plant Soil, 227, 265-272, 2000.

Juottonen, H., Galand, P. E., Tuittila, E.-S., Laine, J., Fritze, H., and Yrjälä, K.: Methanogen communities and Bacteria along an ecohydrological gradient in a northern raised bog complex, Environ. Microbiol., 7, 1547-1557, https://doi.org/10.1111/j.14622920.2005.00838.x, 2005.
Kelker, D. and Chanton, J.: The effect of clipping on methane emissions from Carex, Biogeochemistry, 39, 37-44, https://doi.org/10.1023/A:1005866403120, 1997.

King, G. M.: Associations of methanotrophs with the roots and rhizomes of aquatic vegetation, Appl. Environ. Microb., 60, 32203227, 1994.

King, J. Y., Reeburgh, W. S., and Regli, S. K.: Methane emission and transport by arctic sedges in Alaska: Results of a vegetation removal experiment, J. Geophys. Res.-Atmos., 103, 2908329092, https://doi.org/10.1029/98JD00052, 1998.

Kirschke, S., Bousquet, P., Ciais, P., Saunois, M., Canadell, J. G., Dlugokencky, E. J., Bergamaschi, P., Bergmann, D., Blake, D. R., Bruhwiler, L., Cameron-Smith, P., Castaldi, S., Chevallier, F., Feng, L., Fraser, A., Heimann, M., Hodson, E. L., Houweling, S., Josse, B., Fraser, P. J., Krummel, P. B., Lamarque, J.F., Langenfelds, R. L., Le Quéré, C., Naik, V., O’Doherty, S., Palmer, P. I., Pison, I., Plummer, D., Poulter, B., Prinn, R. G., Rigby, M., Ringeval, B., Santini, M., Schmidt, M., Shindell, D. T., Simpson, I. J., Spahni, R., Steele, L. P., Strode, S. A., Sudo, K., Szopa, S., van der Werf, G. R., Voulgarakis, A., van Weele, M., Weiss, R. F., Williams, J. E., and Zeng, G.: Three decades of global methane sources and sinks, Nat. Geosci., 6, 813-823, https://doi.org/10.1038/ngeo1955, 2013.

Koelbener, A., Ström, L., Edwards, P. J., and Olde Venterink, H.: Plant species from mesotrophic wetlands cause relatively high methane emissions from peat soil, Plant Soil, 326, 147-158, https://doi.org/10.1007/s11104-009-9989-x, 2010.

Kokkonen, N. A. K., Laine, A. M., Laine, J., Vasander, H., Kurki, K., Gong, J., and Tuittila, E.-S.: Responses of peatland vegetation to 15 -year water level drawdown as mediated by fertility level, J. Veg. Sci., 30, 1206-1216, https://doi.org/10.1111/jvs.12794, 2019.

Korrensalo, A., Kettunen, L., Laiho, R., Alekseychik, P., Vesala, T., Mammarella, I., and Tuittila, E.-S.: Boreal bog plant communities along a water table gradient differ in their standing biomass but not their biomass production, J. Veg. Sci., 29, 136146, https://doi.org/10.1111/jvs.12602, 2018a.

Korrensalo, A., Männistö, E., Alekseychik, P., Mammarella, I., Rinne, J., Vesala, T., and Tuittila, E.-S.: Small spatial variability in methane emission measured from a wet patterned boreal bog, Biogeosciences, 15, 1749-1761, https://doi.org/10.5194/bg-151749-2018, 2018b.

Kutzbach, L., Wagner, D., and Pfeiffer, E.-M.: Effect of microrelief and vegetation on methane emission from wet polygonal tundra, Lena Delta, Northern Siberia, Biogeochemistry, 69, 341-362, https://doi.org/10.1023/B:BIOG.0000031053.81520.db, 2004.

Lai, D. Y. F.: Methane Dynamics in Northern Peatlands: A Review, Pedosphere, 19, 409-421, https://doi.org/10.1016/S10020160(09)00003-4, 2009.

Laine, J., Komulainen, V.-M., Laiho, R., Minkkinen, K., Rasinmäki, A., Sallantaus, T., Sarkkola, S., Silvan, N., Tolonen, K., Tuittila, E.-S., Vasander, H., and Päivänen, J.: Lakkasuo - a guide to mires ecosystem, Department of Forest Ecology, University of Helsinki, 31, 123 pp., 2004.

Laine, A., Wilson, D., Kiely, G., and Byrne, K. A.: Methane flux dynamics in an Irish lowland blanket bog, Plant Soil, 299, 181193, https://doi.org/10.1007/s11104-007-9374-6, 2007a.

Laine, A., Byrne, K. A., Kiely, G., and Tuittila, E.-S.: Patterns in Vegetation and $\mathrm{CO}_{2}$ Dynamics along a Water Level Gra- 
dient in a Lowland Blanket Bog, Ecosystems, 10, 890-905, https://doi.org/10.1007/s10021-007-9067-2, 2007b.

Larmola, T., Tuittila, E.-S., Tiirola, M., Nykänen, H., Martikainen, P. J., Yrjälä, K., Tuomivirta, T., and Fritze, H.: The role of Sphagnum mosses in the methane cycling of a boreal mire, Ecology, 91, 2356-2365, https://doi.org/10.1890/09-1343.1, 2010.

Le Mer, J. and Roger, P.: Production, oxidation, emission and consumption of methane by soils: A review, Eur. J. Soil Biol., 37, 25-50, https://doi.org/10.1016/S1164-5563(01)01067-6, 2001.

Leppälä, M., Oksanen, J., and Tuittila, E.-S.: Methane flux dynamics during mire succession, Oecologia, 165, 489-499, https://doi.org/10.1007/s00442-010-1754-6, 2011.

Mäkiranta, P., Laiho, R., Mehtätalo, L., Straková, P., Sormunen, J., Minkkinen, K., Penttilä, T., Fritze, H., and Tuittila, E.-S.: Responses of phenology and biomass production of boreal fens to climate warming under different water-table level regimes, Glob. Change Biol., 24, 944-956, https://doi.org/10.1111/gcb.13934, 2018.

Moore, T. R. and Roulet, N. T.: Methane flux: Water table relations in northern wetlands, Geophys. Res. Lett., 20, 587-590, https://doi.org/10.1029/93GL00208, 1993.

Moore, T. R., Bubier, J. L., and Bledzki, L.: Litter Decomposition in Temperate Peatland Ecosystems: The Effect of Substrate and Site, Ecosystems, 10, 949-963, https://doi.org/10.1007/s10021007-9064-5, 2007.

Moosavi, S. C., Crill, P. M., Pullman, E. R., Funk, D. W., and Peterson, K. M.: Controls on $\mathrm{CH}_{4}$ flux from an Alaskan boreal wetland, Global Biogeochem. Cy., 10, 287-296, https://doi.org/10.1029/96GB00358, 1996.

Munir, T. M. and Strack, M.: Methane Flux Influenced by Experimental Water Table Drawdown and Soil Warming in a Dry Boreal Continental Bog, Ecosystems, 17, 1271-1285, https://doi.org/10.1007/s10021-014-9795-z, 2014.

Myhre, G., Shindell, D., Bréon, F.-M., Collins, W., Fuglestvedt, J., Huang, J., Koch, D., Lamarque, J.-F., Lee, D., Mendoza, B., Nakajima, T., Robock, A., Stephens, G., Takemura, T., and Zhang, H.: Anthropogenic and Natural Radiative Forc-ing, in: Climate Change 2013: The Physical Science Basis. Contribution of Working Group I to the Fifth Assessment Report of the Intergovernmental Panel on Climate Change, edited by: Stocker, T. F., Qin, D., Plattner, G.-K., Tignor, M., Allen, S. K., Boschung, J., Nauels, A., Xia, Y., Bex, V., and Midgley, P. M., Cambridge University Press, Cambridge, UK and New York, NY, USA, 2013.

Noyce, G. L., Varner, R. K., Bubier, J. L., and Frolking, S.: Effect of Carex rostrata on seasonal and interannual variability in peatland methane emissions: effect of C. rostrata on $\mathrm{CH}_{4}$ emissions, J. Geophys. Res.-Biogeo., 119, 24-34, https://doi.org/10.1002/2013JG002474, 2014.

Olefeldt, D., Euskirchen, E. S., Harden, J., Kane, E., McGuire, A. D., Waldrop, M. P., and Turetsky, M. R.: A decade of boreal rich fen greenhouse gas fluxes in response to natural and experimental water table variability, Glob. Change Biol., 23, 2428-2440, https://doi.org/10.1111/gcb.13612, 2017.

Pearce, D. M. E. and Clymo, R. S.: Methane oxidation in a peatland core, Glob. Biogeochem. Cy., 15, 709-720, https://doi.org/10.1029/2000GB001323, 2001.

Pearson, M., Penttilä, T., Harjunpää, L., Laiho, R., Laine, J., Sarjala, T., Silvan, K., and Silvan, N.: Effects of temperature rise and water-table-level drawdown on greenhouse gas fluxes of boreal sedge fens, Boreal Environ. Res., 20, 489-505, 2015.

Peltoniemi, K., Laiho, R., Juottonen, H., Bodrossy, L., Kell, D. K., Minkkinen, K., Mäkiranta, P., Mehtätalo, L., Penttilä, T., Siljanen, H. M. P., Tuittila, E.-S., Tuomivirta, T., and Fritze, H.: Responses of methanogenic and methanotrophic communities to warming in varying moisture regimes of two boreal fens, Soil Biol. Biochem., 97, 144-156, https://doi.org/10.1016/j.soilbio.2016.03.007, 2016.

Popp, T. J., Chanton, J. P., Whiting, G. J., and Grant, N.: Evaluation of methane oxidation in therhizosphere of a Carex dominated fen in northcentral Alberta, Canada, Biogeochemistry, 51, 259-281, https://doi.org/10.1023/A:1006452609284, 2000.

Putkinen, A., Larmola, T., Tuomivirta, T., Siljanen, H. M. P., Bodrossy, L., Tuittila, E.-S., and Fritze, H.: Water Dispersal of Methanotrophic Bacteria Maintains Functional Methane Oxidation in Sphagnum Mosses, Front. Microbiol., 3, 15, https://doi.org/10.3389/fmicb.2012.00015, 2012.

Raghoebarsing, A. A., Smolders, A. J. P., Schmid, M. C., Rijpstra, W. I. C., Wolters-Arts, M., Derksen, J., Jetten, M. S. M., Schouten, S., Damsté, J. S. S., Lamers, L. P. M., Roelofs, J. G. M., den Camp, H. J. M. O., and Strous, M.: Methanotrophic symbionts provide carbon for photosynthesis in peat bogs, Nature, 436, 1153-1156, https://doi.org/10.1038/nature03802, 2005.

Rask, H., Schoenau, J., and Anderson, D.: Factors influencing methane flux from a boreal forest wetland in Saskatchewan, Canada, Soil Biol. Biochem., 34, 435-443, https://doi.org/10.1016/S0038-0717(01)00197-3, 2002.

Rinnan, R., Impiö, M., Silvola, J., Holopainen, T., and Martikainen, P. J.: Carbon dioxide and methane fluxes in boreal peatland microcosms with different vegetation cover-effects of ozone or ultraviolet-B exposure, Oecologia, 137, 475-483, https://doi.org/10.1007/s00442-003-1366-5, 2003.

Rinne, J., Riutta, T., Pihlatie, M., Aurela, M., Haapanala, S., Tuovinen, J.-P., Tuittila, E.-S., and Vesala, T.: Annual cycle of methane emission from a boreal fen measured by the eddy covariance technique, Tellus B, 59, 449-457, https://doi.org/10.1111/j.16000889.2007.00261.x, 2007.

Rinne, J., Tuittila, E.-S., Peltola, O., Li, X., Raivonen, M., Alekseychik, P., Haapanala, S., Pihlatie, M., Aurela, M., Mammarella, I., and Vesala, T.: Temporal Variation of Ecosystem Scale Methane Emission From a Boreal Fen in Relation to Temperature, Water Table Position, and Carbon Dioxide Fluxes, Global Biogeochem. Cy., 32, 1087-1106, https://doi.org/10.1029/2017GB005747, 2018.

Riutta, T., Laine, J., and Tuittila, E.-S.: Sensitivity of $\mathrm{CO}_{2}$ Exchange of Fen Ecosystem Components to Water Level Variation, Ecosystems, 10, 718-733, https://doi.org/10.1007/s10021-007-9046-7, 2007a.

Riutta, T., Laine, J., Aurela, M., Rinne, J., Vesala, T., Laurila, T., Haapanala, S., Pihlatie, M., and Tuittila, E.-S.: Spatial variation in plant community functions regulates carbon gas dynamics in a boreal fen ecosystem, Tellus B, 59, 838-852, https://doi.org/10.1111/j.1600-0889.2007.00302.x, 2007b.

Riutta, T., Korrensalo, A., Laine, A., Laine, J., and Tuittila, E.-S.: Chamber measurements of $\mathrm{CH}_{4}$ efflux and environmental variables from Lakkasuo peatland, Southern Finland, PANGAEA, https://doi.org/10.1594/PANGAEA.911742, 2020a. 
Riutta, T., Korrensalo, A., Laine, A., Laine, J., and Tuittila, E.-S.: Annual chamber measurements of $\mathrm{CH}_{4}$ efflux and environmental variables from Lakkasuo peatland, Southern Finland, PANGAEA, https://doi.org/10.1594/PANGAEA.911740, 2020 b.

Robroek, B. J. M., Jassey, V. E. J., Kox, M. A. R., Berendsen, R. L., Mills, R. T. E., Cécillon, L., Puissant, J., Meima-Franke, M., Bakker, P. A. H. M., and Bodelier, P. L. E.: Peatland vascular plant functional types affect methane dynamics by altering microbial community structure, edited by N. Wurzburger, J. Ecol., 103, 925-934, https://doi.org/10.1111/1365-2745.12413, 2015.

Roura-Carol, M. and Freeman, C.: Methane release from peat soils: effects of Sphagnum and Juncus, Soil Biol. Biochem., 31, 323325, https://doi.org/10.1016/S0038-0717(98)00125-4, 1999.

Saunois, M., Bousquet, P., Poulter, B., Peregon, A., Ciais, P., Canadell, J. G., Dlugokencky, E. J., Etiope, G., Bastviken, D., Houweling, S., Janssens-Maenhout, G., Tubiello, F. N., Castaldi, S., Jackson, R. B., Alexe, M., Arora, V. K., Beerling, D. J., Bergamaschi, P., Blake, D. R., Brailsford, G., Brovkin, V., Bruhwiler, L., Crevoisier, C., Crill, P., Covey, K., Curry, C., Frankenberg, C., Gedney, N., Höglund-Isaksson, L., Ishizawa, M., Ito, A., Joos, F., Kim, H.-S., Kleinen, T., Krummel, P., Lamarque, J.-F., Langenfelds, R., Locatelli, R., Machida, T., Maksyutov, S., McDonald, K. C., Marshall, J., Melton, J. R., Morino, I., Naik, V., O'Doherty, S., Parmentier, F.-J. W., Patra, P. K., Peng, C., Peng, S., Peters, G. P., Pison, I., Prigent, C., Prinn, R., Ramonet, M., Riley, W. J., Saito, M., Santini, M., Schroeder, R., Simpson, I. J., Spahni, R., Steele, P., Takizawa, A., Thornton, B. F., Tian, H., Tohjima, Y., Viovy, N., Voulgarakis, A., van Weele, M., van der Werf, G. R., Weiss, R., Wiedinmyer, C., Wilton, D. J., Wiltshire, A., Worthy, D., Wunch, D., Xu, X., Yoshida, Y., Zhang, B., Zhang, Z., and Zhu, Q.: The global methane budget 2000-2012, Earth Syst. Sci. Data, 8, 697-751, https://doi.org/10.5194/essd-8-697-2016, 2016.

Scheffer, R. A. and Aerts, R.: Root decomposition and soil nutrient and carbon cycling in two temperate fen ecosystems, Oikos, 91, 541-549, https://doi.org/10.1034/j.16000706.2000.910316.x, 2000.

Schimel, J. P.: Plant transport and methane production as controls on methane flux from arctic wet meadow tundra, Biogeochemistry, 28, 183-200, https://doi.org/10.1007/BF02186458, 1995.

Shannon, R. D., White, J. R., Lawson, J. E., and Gilmour, B. S.: Methane Efflux from Emergent Vegetation in Peatlands, J. Ecol., 84, 239-246, https://doi.org/10.2307/2261359, 1996.

Strack, M. and Waddington, J. M.: Response of peatland carbon dioxide and methane fluxes to a water table drawdown experiment, Global Biogeochem. Cy., 21, GB1007, https://doi.org/10.1029/2006GB002715, 2007.

Strack, M., Waddington, J. M., and Tuittila, E.-S.: Effect of water table drawdown on northern peatland methane dynamics: Implications for climate change: northern peatland $\mathrm{CH}_{4}$ dynamics and climate change, Global Biogeochem. Cy., 18, GB4003, https://doi.org/10.1029/2003GB002209, 2004.

Strack, M., Waller, M. F., and Waddington, J. M.: Sedge Succession and Peatland Methane Dynamics: A Potential Feedback to Climate Change, Ecosystems, 9, 278-287, https://doi.org/10.1007/s10021-005-0070-1, 2006.

Strack, M., Mwakanyamale, K., Hassanpour Fard, G., Bird, M., Bérubé, V., and Rochefort, L.: Effect of plant functional type on methane dynamics in a restored minerotrophic peatland, Plant
Soil, 410, 231-246, https://doi.org/10.1007/s11104-016-2999-6, 2017.

Ström, L., Mastepanov, M., and Christensen, T. R.: Speciesspecific Effects of Vascular Plants on Carbon Turnover and Methane Emissions from Wetlands, Biogeochemistry, 75, 65-82, https://doi.org/10.1007/s10533-004-6124-1, 2005.

Ström, L., Tagesson, T., Mastepanov, M., and Christensen, T. R.: Presence of Eriophorum scheuchzeri enhances substrate availability and methane emission in an Arctic wetland, Soil Biol. Biochem., 45, 61-70, https://doi.org/10.1016/j.soilbio.2011.09.005, 2012.

Sun, X., Song, C., Guo, Y., Wang, X., Yang, G., Li, Y., Mao, R., and $\mathrm{Lu}, \mathrm{Y}$.: Effect of plants on methane emissions from a temperate marsh in different seasons, Atmos. Environ., 60, 277-282, https://doi.org/10.1016/j.atmosenv.2012.06.051, 2012.

Thormann, M. N., Bayley, S. E., and Currah, R. S.: Comparison of decomposition of belowground and aboveground plant litters in peatlands of boreal Alberta, Canada, Can. J. Bot., 79, 9-22, https://doi.org/10.1139/cjb-79-1-9, 2001.

Turetsky, M. R., Treat, C. C., Waldrop, M. P., Waddington, J. M., Harden, J. W., and McGuire, A. D.: Short-term response of methane fluxes and methanogen activity to water table and soil warming manipulations in an Alaskan peatland, J. Geophys. Res., 113, G00A10, https://doi.org/10.1029/2007JG000496, 2008.

Turetsky, M. R., Kotowska, A., Bubier, J., Dise, N. B., Crill, P., Hornibrook, E. R. C., Minkkinen, K., Moore, T. R., Myers-Smith, I. H., Nykänen, H., Olefeldt, D., Rinne, J., Saarnio, S., Shurpali, N., Tuittila, E.-S., Waddington, J. M., White, J. R., Wickland, K. P., and Wilmking, M.: A synthesis of methane emissions from 71 northern, temperate, and subtropical wetlands, Glob. Change Biol., 20, 2183-2197, https://doi.org/10.1111/gcb.12580, 2014.

Waddington, J. M. and Roulet, N. T.: Carbon balance of a boreal patterned peatland, Glob. Change Biol., 6, 87-97, https://doi.org/10.1046/j.1365-2486.2000.00283.x, 2000.

Waddington, J. M., Roulet, N. T., and Swanson, R. V.: Water table control of $\mathrm{CH}_{4}$ emission enhancement by vascular plants in boreal peatlands, J. Geophys. Res.-Atmos., 101, 22775-22785, https://doi.org/10.1029/96JD02014, 1996.

Ward, S. E., Ostle, N. J., Oakley, S., Quirk, H., Henrys, P. A., and Bardgett, R. D.: Warming effects on greenhouse gas fluxes in peatlands are modulated by vegetation composition, Ecol. Lett., 16, 1285-1293, https://doi.org/10.1111/ele.12167, 2013.

Whalen, S. C.: Biogeochemistry of Methane Exchange between Natural Wetlands and the Atmosphere, Environ. Eng. Sci., 22, 73-94, https://doi.org/10.1089/ees.2005.22.73, 2005.

Whalen, S. C. and Reeburgh, W. S.: Methane Oxidation, Production, and Emission at Contrasting Sites in a Boreal Bog, Geomicrobiol. J., 17, 237-251, https://doi.org/10.1080/01490450050121198, 2000.

Wilson, D., Alm, J., Riutta, T., Laine, J., Byrne, K. A., Farrell, E. P., and Tuittila, E.-S.: A high resolution green area index for modelling the seasonal dynamics of $\mathrm{CO}_{2}$ exchange in peatland vascular plant communities, Plant Ecol., 190, 37-51, https://doi.org/10.1007/s11258-006-9189-1, 2007.

Yavitt, J. B., Williams, C. J., and Wieder, R. K.: Controls on Microbial Production of Methane and Carbon Dioxide in Three Sphagnum-Dominated Peatland Ecosystems as Revealed by a 
Reciprocal Field Peat Transplant Experiment, Geomicrobiol. J., 17, 61-88, https://doi.org/10.1080/014904500270503, 2000.

Yavitt, J. B., Kryczka, A. K., Huber, M. E., Pipes, G. T., and Rodriguez, A. M.: Inferring Methane Production by Decomposing Tree, Shrub, and Grass Leaf Litter in Bog and Rich Fen Peatlands, Front. Environ. Sci., 7, 182, https://doi.org/10.3389/fenvs.2019.00182, 2019.

Yrjälä, K., Tuomivirta, T., Juottonen, H., Putkinen, A., Lappi, K., Tuittila, E.-S., Penttilä, T., Minkkinen, K., Laine, J., Peltoniemi, K., and Fritze, H.: $\mathrm{CH}_{4}$ production and oxidation processes in a boreal fen ecosystem after long-term water table drawdown: $\mathrm{CH}_{4}$ production and oxidation processes, Glob. Change Biol., 17, 1311-1320, https://doi.org/10.1111/j.13652486.2010.02290.x, 2011.
Yu, Z. C.: Northern peatland carbon stocks and dynamics: a review, Biogeosciences, 9, 4071-4085, https://doi.org/10.5194/bg9-4071-2012, 2012. 